\title{
Nos gramados do Sul: a seleção baiana de futebol e o torneio do Centenário da Independência em 1922
}

\section{In the Southern fields: the Bahia state soccer team and the Centenary of Independence championship of 1922}

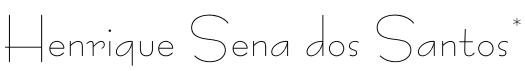

\section{Apresentação}

O I Centenário da Independência oportunizou, para o país, refletir sobre sua identidade nacional e também repensar a sua inserção na modernidade ${ }^{1}$. Em comemoração à data, uma exposição internacional foi realizada com o objetivo de mostrar aos visitantes estrangeiros o progresso do país ${ }^{2}$. Na historiografia brasileira, muito pouco se tem discutido sobre o evento. Nesta produção, predomina a análise sobre como os estados de São Paulo e Rio de Janeiro relacionaram-se com o festejo $^{3}$. Outra via bastante comum é uma discussão voltada para os aspectos simbólicos das comemorações, considerando o Centenário como um momento de fortalecimento da nação e dos seus mitos fundadores, ambos engendrados no processo da

\footnotetext{
* Doutorando em História pela Universidade Estadual Paulista - Unesp/Campus de Assis. E-mail: henrisena@hotmail.com

${ }^{1}$ Sobre esta relação, sugiro: TENORIO, Mauricio. Um Cuauhtémoc carioca: comemorando o Centenário da Independência do Brasil e a raça cósmica. Estudos Históricos, Rio de Janeiro, v. 7, n. 14, 1994.

${ }^{2}$ Sobre a exposição Internacional, ver: SANT'ANA, Thais Rezende da Silva. A Exposição Internacional do Centenário da Independência: Modernidade e Política no Rio de Janeiro do início dos anos 1920. Dissertação (Mestrado em História), Campinas: IFCH, Unicamp, 2008.

${ }^{3}$ MOTTA, Marly Silva da. A nação faz 100 anos: questão nacional no Centenário da Independência. Rio de Janeiro: Ed. da Fundação Getúlio Vargas-CPDOC, 1992; LUCA, Tania Regina de. O Centenário da Independência em São Paulo. História. Debates e Tendências, Passo Fundo, v. 4, n. 2, p. 136-150, 2003.
} 
Independência ${ }^{4}$. Embora relevantes, tais perspectivas deixam escapar o engajamento dos estados distantes do centro político do país nos festejos do Centenário, ou mesmo as possiveis tensões entre as identidades regionais escamoteadas no momento de celebração da identidade nacional.

Diante de uma lacuna historiográfica, nossa preocupação, neste artigo, foi recuperar as comemorações do I Centenário da Independência a partir da realização do I Campeonato Brasileiro de Seleções, também conhecido pelo nome de Torneio do Centenário. Este certame foi idealizado pela Confederação Brasileira de Desportos, a CBD, como seletiva para formar um combinado nacional que disputaria o VI Campeonato Sul Americano, no Brasil, além de ter servido como um evento esportivo comemorativo do I Centenário da Independência. A partir desse campeonato, foi possivel perceber uma tensão existente entre a Bahia, que na sua participação no evento desejava adquirir uma centralidade no processo de consolidação de uma identidade nacional, e as tentativas da Confederação Brasileira de Desportos em restringir e prejudicar a participação do Norte no torneio, revogando para si a elaboração de uma identidade nacional por meio do futebol.

As principais fontes utilizadas neste artigo foram as notícias veiculadas pela revista Semana Sportiva, principal publicação esportiva da cidade de Salvador, sobre a presença do estado no Torneio do Centenário e como a CBD o organizou. A competição, realizada no mês de agosto de 1922, envolveria partidas entre os estados que eram confederados à CBD. Após as eliminatórias regionais, os respectivos vencedores se reuniriam para a disputa dos jogos finais na capital da República. Podemos considerar que, ao também ser pensado enquanto uma seletiva para a formação de uma seleção brasileira para o VI Campeonato Sul Americano, parecia haver um esforço por parte da Confederação em formar uma seleção efetivamente nacional, demonstrando, assim, uma preocupação em exaltar a unidade nacional em uma data expressiva.

${ }^{4}$ SANDES, Noé Freire. A invenção da nação: entre a monarquia e a república. Goiânia: UFG, 2000. Para uma análise aprofundada sobre os mitos fundadores da República, sugiro: CARVALHO, José Murilo de. A formação das almas: o imaginário da República no Brasil. São Paulo: Companhia das Letras, 1990. 
Para alguns periódicos soteropolitanos, a participação da Bahia e a desistência de outros estados do norte foram marcadas por tentativas da CBD em restringir ou prejudicar a participação da citada região no certame. Diante da postura da entidade máxima dos esportes brasileiros e da preocupação da Bahia em ter um espaço legítimo na ideia de nação que se fortalecia, foi possivel perceber como, no Torneio do Centenário e no I Centenário da Independência, a tentativa de fortalecimento da identidade nacional através do futebol ainda era marcada, de maneira profunda, por tensões regionais que historicamente constituíram a própria ideia de nacionalidade brasileira.

\section{Antecedentes e preparativos para o torneio}

Nos meses que antecederam a competição, foram encontradas muitas referências nos periódicos de Salvador sobre a participação da Bahia no certame. Sobretudo em opiniões de cronistas, na forma de colunas e editoriais, a imprensa especializada constantemente tecia comentários acerca da importância da participação do estado no torneio.

Um ano antes, em 1921, os jornais e revistas já se preocupavam como a Liga Bahiana de Desportos Terrestres, a LBDT, principal instituição gestora do futebol baiano, organizaria uma seleção para a disputa do Torneio do Centenário. Um editorial da revista Semana Sportiva, por exemplo, queixava-se do fato de a entidade ainda não ter organizado treinos, seleções e preparações. Segundo o texto, o que deveria ser feito "para o renome da Bahia, se se pretende tomar parte nas festas do Centenário, é, desde já, intensificar os treinamentos e submeter, de quando em quando, os selecionados até a época de serem realizadas as aludidas festas" ${ }^{5}$. Sobre o dito descaso da LBDT, a revista finalizava com uma espécie de conclamação:

É tempo, senhores, de sairmos deste caos a que nos temos condenados.

Não é possível, depois de sermos os primeiros em tudo neste grande país, retrogradarmos até a nulidade.

\footnotetext{
${ }^{5}$ Semana Sportiva. Salvador, n. 9, 8 de junho de 1921.
} 
E para chegarmos ao que fomos é preciso que nos unamos fraternalmente, que os baianos formem um só corpo, pulsando neste grande coração a grandeza da Bahia.

E para chegarmos ao que já fomos é tão grande o contágio das suas contorções e delírios que nivela as multidões todos fundidos numa só alma. Unidos firmaremos num único pensamento elevar o nome da nossa querida Bahia com a presunção única de sermos os primeiros entre os primeiros e seremos.

A postos! 6

O editorial foi publicado quando faltava mais de um ano para a realização do torneio, revelando a dimensão que o certame, naquela altura, adquiria para a imprensa local. De certo modo, com o advento da República, ocorreu a perda de prestígio do estado, em decorrência dos rearranjos politicos e sociais, dos quais novos grupos regionais ascenderam no plano nacional. Já no início do século XIX, Salvador deixou de ser a capital do Brasil, somando-se a isso a gradativa estagnação econômica causada pela crise açucareira, além da dificuldade da Bahia em se inserir de modo mais contundente na dinâmica econômica industrial $^{7}$. Esses e outros fatores fizeram com que os baianos chegassem ao alvorecer da República em uma condição política e econômica relativamente periférica se comparada à de São Paulo, Rio de Janeiro e Minas Gerais. Desse modo, através de uma operação de identidade na qual se procurava proferir um discurso historicamente constituído na tradição, no pioneirismo dos baianos ou nas grandezas da terra, há uma tentativa, sobretudo entre as elites baianas, de recuperação da centralidade da Bahia no país, de maneira que a participação no Torneio do Centenário corroborasse as pretensões daquele grupo social ${ }^{8}$.

Devido aos contornos que o evento adquiria para os baianos, não só os jornalistas locais queixavam-se da relativa falta

\footnotetext{
${ }^{6}$ Idem.

${ }^{7}$ Sobre as dificuldades econômicas enfrentadas pela Bahia entre a transição dos séculos XIX e XX, ver: AGUIAR, M. P. de. "Notas sobre o 'enigma baiano.'” Revista Planejamento. Salvador, v. 5, n. 4, p. 123-136, out/dez. 1977; TAVARES, Luís Henrique Dias. O problema da involução industrial da Bahia. Salvador: EDUFBA, 1966.

${ }^{8}$ Sobre a tentativa das elites baianas, através do discurso, de recuperar a importância do estado no cenário nacional, ver: LEITE, Rinaldo Cesar Nascimento. A Rainha Destronada: discursos das elites sobre as grandezas e os infortúnios da Bahia nas primeiras décadas republicanas. Tese (Doutorado em História) - PUC-SP, 2005.
} 
Nos gramados do Sul: a seleção baiana de futebol e o torneio do Centenário da ...

de iniciativa da LBDT em organizar treinamentos e seleções visando o torneio. Muitas vezes os jornais e, principalmente, a Semana Sportiva ofereciam em suas páginas um espaço para cartas, sugestões e opiniões de leitores. Com alguma regularidade, foi possivel encontrar correspondências que versavam sobre a participação da Bahia nas festas esportivas do Centenário. Como de costume, uma opinião de um leitor, cuja identidade é desconhecida, criticava, dessa vez, a postura não só da LBDT, mas, também, dos clubes a ela filiados. De título "E a Bahia?", a carta argumentava:

Onde nasceu esse colosso que se chama Brasil, sofrendo do mal que contamina este gigante, deixa-se estar nesta astenia, nesta morbidez atroz.

Se nos fosse pedido o diagnóstico apontávamos para a nata que, ao em vez de ser o elemento puro socialmente falando, é, no entanto, o resultado da fermentação os resíduos, a causa do atavismo da nossa evolução, pelos defeitos adquiridos da mania de supremacia, da diferença que quer ter dos da mesma família.

Falta unicamente dos que dirigem os esportes que, em vez de procurarem influir, animar, organizar, vivem unicamente a se preocuparem com questões sem importância, caprichos banais e nada mais. ${ }^{9}$

Esse tipo de crítica era recorrente, uma vez que o futebol em Salvador vivia permeado por tensões entre os clubes e jogadores; a sugestão do leitor, portanto, consiste em sugerir que esses conflitos sejam postos de lado em prol de um bem maior. Finalmente, quando diz que o Brasil nasceu na Bahia, o leitor ratifica a ideia de pioneirismo das elites baianas, talvez numa tentativa de persuadir os dirigentes esportivos sobre a necessidade eminente da participação do estado no Torneio, confirmando a sua suposta grandeza.

É possivel imaginar que tamanha insatisfação com a falta de organização da LBDT esteja ligada ao fato de que os outros estados já estarem se preparando para os festejos. No esporte, as comemorações do Centenário envolveriam não só a disputa de um campeonato de futebol, mas também as Olimpiadas do Centenário, nas quais seria realizada uma série de eventos esportivos atléticos, náuticos, entre outros. Em dezembro de

\footnotetext{
${ }^{9}$ Semana Sportiva. Salvador, n. 50, 18 de março de 1922.
} 
1921, algumas atividades seriam realizadas como ensaio para as Olimpiadas, inscrevendo-se entidades esportivas do Rio de Janeiro, do exército, da marinha, de São Paulo, de Minas Gerais, do Espírito Santo e de Santos. Mais uma vez, a ausência da Bahia não passou despercebida pela imprensa local, como ficou explícito em uma matéria cujo título é semelhante à carta do leitor:

A nossa liga não recebeu da Confederação, prospectos e regulamentos das Olimpiadas?

Não ordenou que nos dias 14 de julho e 7 de setembro não fossem realizados matchs de foot-ball a fim de ser feita a eliminatória dos atletas baianos que desejam comparecer na Olimpiada?

E o que fez a Liga?

Nada. Não ligou importância a ordem da Confederação! ${ }^{10}$

Ao contrário da opinião do leitor, que atribuía a responsabilidade da desorganização ao descaso direcionado aos clubes, a crítica novamente recaía à entidade máxima do futebol baiano, visto que os clubes que "desejavam preparar os seus atletas para as Olimpiadas, viram-se forçados a desistir visto o pouco caso ou nenhum da Liga Bahiana, que, criminosamente, até a presente data, nada fez nem fará. É o cúmulo! Pobre Bahia! Infeliz terra!"11.

Quando não eram os estados do Sul que se organizavam para as competições a serem realizadas no Rio de Janeiro, eram os estados do Norte que se preparavam com afinco para as festas do Centenário. Nessa região do país, segundo a imprensa especializada, o Pará, Pernambuco, a Bahia e o Ceará, no que diz respeito ao esporte, eram os estados mais organizados, pois na década de 1920 , contavam com praças esportivas, clubes e entidades, como ligas de futebol e remo. Além disso, ao que parece, eram os únicos da região a serem confederados. De acordo com a imprensa esportiva de Salvador, desses quatro estados, a Bahia era a mais atrasada no que tange à organização para as festas na capital republicana, já que é possivel encontrar notícias informando os preparativos dos estados próximos para a participação no evento.

\footnotetext{
${ }^{10}$ Semana Sportiva. Salvador, n. 37, 17 dezembro de 1921.

${ }^{11}$ Idem.
} 
Enfim, ver os vizinhos preparando-se para as comemorações do Centenário parecia ser inaceitável para as elites baianas com as suas pretensões de serem as primeiras em tudo. Noticiando a organização do Pará, mais uma vez a revista Semana Sportiva não deixou de alfinetar a LBDT, ao afirmar que a "nossa entidade máxima, com sua luta de competições, de rivalidades estéreis, não dá o brado para o nosso despertar" ${ }^{12}$. Antes de finalizar a notícia com uma transcrição de um jornal maranhense relatando o quanto os treinamentos dos paraenses para as Olimpíadas do Centenário estavam adiantados, ainda há tempo para a revista novamente conclamar os baianos: "Mas será possível que fiquemos nessa filosofia vergonhosa de nossa falência física? Baianos: acompanhemos com ardor os nossos irmãos do Norte e vamos pelas Olimpiadas disputar com os sulistas a nossa superioridade nos jogos desportivos"13.

Para além do desinteresse em se preparar para as competições do Centenário, ora da LBDT, ora dos seus clubes, as próprias fontes nos possibilitaram abrir outra linha interpretativa para a falta de planejamento e de organização da Bahia esportiva para as festas: um possível descaso e desinteresse da própria CBD dirigido aos estados do Norte. Uma entrevista encontrada na Semana Sportiva é bastante sintomática na compreensão de como a Confederação tratava os nortistas sobre os assuntos do Centenário. Em nome de Amado Coutinho, jornalista do Diário de Notícias, da Semana Sportiva, e membro da Associação de Cronistas Desportivos da Bahia, o cronista baiano D'Almeida Cavalcanti conseguiu uma entrevista com o sportman Professor Reymar que, no Rio de Janeiro, travava um ferrenho debate com o diário carioca $O$ Esporte referente à presença do esporte e do Norte nas festas na capital do país. Seguem trechos da entrevista:

Reymar - É minha opinião que todo o Brasil esportivo comemore ao lado de todas as instituições o Centenário de nossa independência.

D’Almeida - Como: não é todo Brasil esportivo? Há exceções de estados?

\footnotetext{
${ }^{12}$ Semana Sportiva. Salvador, n. 54, 15 de abril de 1922.

${ }^{13}$ Idem.
} 
Reymar - Sim: porque o Brasil não é só o Rio de Janeiro e São Paulo, os outros que me consta, vão concorrer a convite da CDB.

O Brasil são vinte e um estados, um Distrito e um território, o do Acre.

D’Almeida - Perfeitamente, pensa muito acertadamente.

Reymar - Portanto, se assim é o Brasil, por que a Confederação Brasileira Desportos não leva aos seus alcances diretrizes de cultura física, reunindo nos jogos do Centenário o Brasil inteiro? ${ }^{14}$

Continuando a entrevista, o sportman Reymar afirma que é de conhecimento de todos, no Rio de Janeiro, a existência, na Bahia, de um centro de cultura física dirigido por Jayme Ferreira. Diante disso, perguntado por D'Almeida por que não ocorreu uma adesão daquele centro pela Confederação para a disputa das Olimpiadas, Reymar respondeu que "simplesmente a orientação da CBD não chegou ainda até aquele estado"15. Diante da negligência da entidade para com o esporte baiano, é possível considerar que muitas vezes a vontade dos dirigentes esportivos locais esbarrava na considerada "despropositada" inabilidade da Confederação em pensar uma política esportiva efetivamente nacional. Reymar entendia que se houvesse o convite da entidade não só à Bahia como ao Ceará "que, por sua vez, possui bons clubes esportivos e um ótimo centro de cultura fisica, tanto um como outro não se recusariam ao convite, assim lhes fosse proporcionado os elementos e garantias necessárias"16. Ao final, o professor e sportman defendeu que "o Brasil não é só o Rio de Janeiro e São Paulo, é também a Bahia, o Ceará, Pernambuco, enfim são todos os territórios da Federação Brasileira"17.

Caso a afirmação de Reymar, de que não houve uma adesão do centro de cultura física baiano às Olimpíadas do Centenário, seja verídica, talvez a crítica da Semana Sportiva, em dezembro de 1921, não tivesse muita procedência, visto que as orientações para enviarem atletas para os treinamentos das Olimpíadas não teriam chegado. Enfim, entre o dito descaso da LBDT e a desorganização dos clubes e dirigentes baianos,

\footnotetext{
${ }^{14}$ Idem.

${ }^{15}$ Idem.

${ }^{16}$ Idem.

${ }^{17}$ Idem.
} 
Nos gramados do Sul: a seleção baiana de futebol e o torneio do Centenário da ...

poderia existir um possivel menosprezo da CBD que muitas vezes poderia esfriar os ânimos dos sportmen de Salvador.

Diante da relação da CBD com o Norte, àquela altura já bastante explícita nos círculos esportivos da região, uma alternativa foi pensada para se comemorar o Centenário: a criação de um programa esportivo, o Campeonato do Norte, exclusivamente organizado para os estados regionais. A iniciativa caberia à Liga Pernambucana de Desportos Terrestres, na figura de um dos seus membros, Renato Silveira. Em entrevista concedida ao jornal Diário da Bahia, um sportman pernambucano, Cícero Mello, afirmou que a ideia de um campeonato regional surgiu por conta dos desacertos da CBD com as ligas do Norte:

Parece-me coisa problemática, mesmo irrealizável, a ida dos elementos do Norte às provas Olímpicas do Centenário. Não é de hoje o pouco interesse que a Confederação manifesta pela nossa vida desportiva. Precisamos reagir contra esse descaso, mostrando a mentora dos desportos nacionais que o Norte tem atletas em condições de competir com os do Sul da República ${ }^{18}$.

Perguntado sobre o teor do projeto, Cícero respondeu que "além das provas atléticas simples, haverá campeonatos parciais de foot-ball, lawn-tenis, water-polo, remo, natação, ping-pong e criquete"19. Por fim, salientou que "participarão desse campeonato todas as ligas confederadas desde o Amazonas à Bahia"20. A possibilidade de um torneio envolvendo somente os estados do Norte foi bem aceita pela imprensa soteropolitana. No entanto, não se pode dizer o mesmo no que concerne aos dirigentes baianos. Em 12 de agosto de 1922, uma notícia do Jornal Pequeno, de Recife, transcrita pela Semana Sportiva, informava que "das Ligas dos estados do Norte, convidadas por meio de telegramas, a comissão central já recebeu adesões das do Pará, Maranhão e Rio Grande do Norte"21. Quanto aos outros estados, o jornal informava que as "Ligas Amazonense, Piauiense, Cearense e Alagoana, até a presente data, não responderam os convites feitos pela nossa entidade máxima esportiva. A Liga

\footnotetext{
${ }^{18}$ Semana Sportiva. Salvador, n. 47, 25 de fevereiro de 1922.

${ }^{19}$ Idem.

${ }^{20}$ Idem.

${ }^{21}$ Semana Sportiva. Salvador, n. 71, 12 de agosto de 1922.
} 
Bahiana, em resposta ao convite feito pela LPDT, declarou não poder tomar parte nas referidas festas"22. A decisão da entidade baiana, embora conhecida por nós naquela data, revela um comportamento já esperado pela imprensa esportiva local. Alguns meses atrás, em 08 de abril de 1922, a Semana Sportiva, abordando a ideia do Campeonato do Norte, já adiantava sobre qual seria a atitude dos dirigentes esportivos locais diante da iniciativa de Pernambuco:

A compreensão do esporte pela Liga Bahiana comparativamente com os núcleos de outros estados muito nos deixa a desejar. Todos trabalham pelo alevantamento de seu estado, procurando cada qual ter a supremacia no esporte.

Enquanto a Liga Bahiana estrangula o desenvolvimento esportivo, procurando a todo transe restringir, sem se incomodar com a sua representação nas festas do Centenário e tão pouco promover festas para o 2 de julho nem do ano corrente nem do vindouro, Pernambuco envida esforços, não só para festejar o Centenário, como sentido com o descaso da Confederação Brasileira, procura organizar o Campeonato do Norte ${ }^{23}$.

O interesse da revista esportiva pela participação da Bahia no Campeonato do Norte vai ao encontro das intenções da Liga Pernambucana, uma vez que, para o periódico, "é preciso que o Norte dê sinal de que vive, para isso é preciso que haja unidade, tino e força" ${ }^{24}$. Nesse sentido, a comemoração do Centenário passava necessariamente pela demonstração do progresso esportivo do Norte. Se para isso, diante do descaso da CBD, fosse necessária a criação de um campeonato exclusivamente regional, este não seria um problema. Todavia, ao contrário da imprensa baiana, esse pensamento parecia não estar tão claro na mente dos dirigentes locais.

Podemos supor, também, que o fato dos baianos terem declinado o convite para participar do Campeonato do Norte seja uma questão do regionalismo ${ }^{25}$. Talvez fosse inaceitável

\footnotetext{
${ }^{22}$ Idem.

${ }^{23}$ Semana Sportiva. Salvador, n. 53, 08 de abril de 1922.

${ }^{24}$ Idem.

${ }^{25} \mathrm{O}$ regionalismo, aqui, é entendido como um comportamento caracterizado, de um lado, pela aceitação de uma unidade política mais abrangente, mas, de outro, pela busca de certo favoritismo e de certa autonomia de decisão. Sobre o conceito, ver: LOVE, Joseph. A República Brasileira: federalismo e regionalismo (1889-1937). In: MOTA, Carlos Guilherme. (Org.). Viagem Incompleta: a experiência brasileira (1500-2000): a grande transação. São Paulo: Editora SENAC São Paulo, 2000; OLIVEN, Ruben George. O nacional e o regional na construção da identidade brasileira. Revista Brasileira de Ciência Sociais, v. 1, n. 2, p. 68-74, out. 1986.
} 
Nos gramados do Sul: a seleção baiana de futebol e o torneio do Centenário da ...

para dirigentes locais verem Pernambuco liderar o movimento esportivo do Norte em resposta ao considerado bairrismo da CBD. É possivel encontrar diversas referências na imprensa baiana e pernambucana que evidenciam uma rivalidade entre os dois estados, que pareciam disputar a hegemonia politica e esportiva da região. Contudo, essa tensão não inviabilizava uma união, ao menos do ponto de vista discursivo, entre a Bahia e Pernambuco.

Além da não participação da Bahia no Campeonato do Norte, não podemos afirmar se esse torneio realmente existiu. Ao menos nos jornais e periódicos de Salvador, não foram encontradas notícias ou evidências sobre a sua realização. $\mathrm{Na}$ Semana Sportiva, uma notícia transcrita do Jornal do Recife informava que o projeto do Campeonato do Norte aprovado pela Liga Pernambucana "deverá ser submetido ao estudo da Confederação afim de que se pronuncie e dê a necessária autorização para que o desporto de Pernambuco fique com os poderes de organizar o programa" 26 . É provável que o projeto tenha sido aprovado e as entidades esportivas do Norte não conseguiram organizar delegações para a disputa das competições. Talvez o evento tenha sido realizado, porém sem a mesma repercussão adquirida no momento da sua organização. Entretanto, independente da sua existência, uma iniciativa dessa proporção representava a possibilidade do Norte em contrapor a gradativa tentativa da CBD em assumir o controle do esporte nacional e em não se preocupar com uma politica esportiva que, de fato, contemplasse as demandas nacionais.

Embora não saibamos se o Campeonato do Norte existiu, é certo que nem Pernambuco e nem o Pará ou tampouco outro estado nortista tenha tido participação no Torneio do Centenário organizado pela CBD. A parte principal dessa competição ocorreria no Rio de Janeiro. Antes disso, seriam realizadas eliminatórias regionais entre as Ligas. A vaga do Norte seria decidida no dia 23 de julho de 1922. Os estados envolvidos na eliminatória da região foram Bahia, Pará e Pernambuco. Não foi possivel saber o motivo de os outros estados não terem participado dos jogos. Provavelmente não tinham condições de participar ou não eram confederados à $\mathrm{CBD}$, uma exigência da

${ }^{26}$ Semana Sportiva. Salvador, n. 53, 08 de abril de 1922. 
entidade, ou simplesmente não desejaram entrar no torneio. A eliminatória do Norte resultaria de um primeiro jogo em Recife entre Pernambuco e Pará, cujo vencedor enfrentaria a Bahia na decisão da vaga em Salvador. Porém, segundo paraenses e pernambucanos, devido à negligência da CBD em planejar datas das eliminatórias que contemplassem os calendários dos dois estados, aqueles deixaram de participar das eliminatórias e, assim, coube à Bahia representar o Norte do país nas festas do Centenário.

Segundo o Jornal Pequeno de Recife, em notícia transcrita pela Semana Sportiva, o problema das datas foi que os jogos eliminatórios na Bahia foram marcados com 15 dias de antecedência. Durante esse período, Pernambuco e Pará deveriam jogar uma partida em Recife e o vencedor desse jogo ainda iria para a Salvador para a partida final contra os anfitriões na decisão pela vaga do Norte. Logo, se vê o pouco tempo para a organização dos selecionados dos dois estados. Para o jornal:

A CBD o que praticava naquele momento nada mais era do que dar uma esperança aos nortistas de que ela se interessava pelos seus desportos.

Marcava com 15 dias de antecedência, antes o primeiro encontro eliminatório para Pernambuco, devendo durante este lapso de tempo as nossas forças se prepararem para a referida prova e os paraenses organizarem seu quadro e embarcá-lo para Recife!!! Tudo isso vem provar a boa vontade da mão das Ligas nortistas!...27

Diante do problema do calendário, houve a tentativa de adiar o primeiro encontro. Pernambucanos e paraenses desejavam que a partida entre eles fosse realizada no dia 23 de julho, para que então o vencedor jogasse com a Bahia em outra oportunidade. A questão é que, no dia 23, todos os jogos eliminatórios regionais seriam realizados. A Liga paraense "que se atrevera a fazer este pedido, incontinenti, teve a desventura de receber um respeitável não com toda a solenidade" 28 . Aos pernambucanos também foi dito um não quanto ao adiamento dos jogos. Com isso, restou aos dois estados abandonarem a competição. Quanto à Bahia, o Jornal Pequeno acreditou que "a

${ }^{27}$ Semana Sportiva. Salvador, n. 68, 22 de julho de 1922.

${ }^{28}$ Idem. 
Nos gramados do Sul: a seleção baiana de futebol e o torneio do Centenário da ...

boa terra tradicional, nada pôde fazer, pois isolada como está em absoluto não irá ao Rio bater-se com os sulistas, representando o Norte do país"29. Devido a essas circunstâncias, restou ao jornal de Recife a costumeira crítica à CBD:

E assim, mais uma vez ficou provado que a Confederação Brasileira de Desportos, não desmentindo a sua opulenta trajetória, somente deseja do Norte os níqueis anuais e que o resto os cultores dos desportos que vão plantar batatas.

É que a CBD ainda continua com a mania de aproveitar as ocasiões oportunas para pilheriar com as Ligas desportivas do Norte. ${ }^{30}$

Porém, ao contrário do que pensava o Jornal Pequeno, os baianos não deixariam de participar do torneio. Segundo a Semana Sportiva, enganado "andou o cronista pernambucano acreditando que a Bahia desportiva não tomasse parte no grande certame brasileiro. Não nos faltaria o brio necessário para transpor todos os obstáculos, todos os empecilhos postos no nosso caminho"31.

Não é dificil imaginar por que a Bahia não deixou de participar do Torneio do Centenário, pois restava apenas esperar o dia 23 para enfrentar Pernambuco ou Pará, jogando nos seus domínios. Para representar o Norte, o Pará, por exemplo, teria que, em 15 dias, ir ao Recife e, caso vencesse os anfitriões, ainda se deslocaria para Salvador no duelo com os baianos em um período no qual reside uma relativa dificuldade quanto aos deslocamentos de longa distância. Uma viagem entre o Pará e a Bahia durava, pelo menos, dois ou três dias de navio, o único transporte disponível para esse tipo de translado.

De fato, a situação da Bahia era mais cômoda e menos dispendiosa. Além disso, é possível que os baianos já estivessem se preparando há mais tempo para o torneio. Inclusive, talvez o estado tenha desistido do futuro Campeonato do Norte em virtude de uma melhor preparação para o Torneio do Centenário. Embora, assim como as delegações paraense e pernambucana, a LBDT tenha recebido oficio da CBD no dia 8 de julho, portanto

\footnotetext{
${ }^{29}$ Idem.

${ }^{30}$ Idem.

${ }^{31}$ Idem.
} 
com 15 dias de antecedência, desde 1921 já se pode encontrar na imprensa notícias sobre a necessidade do estado em se preparar para o evento esportivo.

$\mathrm{Na}$ imprensa local, não foram descobertas evidências que indicam o motivo da Bahia ser privilegiada na organização da eliminatória regional. Dos três estados, era o único que não precisaria jogar duas vezes, tampouco teria que viajar para enfrentar seus adversários. Ademais, nos periódicos da cidade não encontramos manifestações de solidariedade dos baianos para com Pernambuco e Pará, engrossando os protestos a favor dos vizinhos no que tange à mudança da data das eliminatórias regionais do Norte. Como a decisão final da vaga da região ocorreria na Bahia, seus dirigentes esportivos provavelmente calaram-se. Com isso, é possivel imaginar que, quando a CBD favorecia a Bahia, colocando-a em uma posição mais privilegiada do que a dos seus vizinhos, o discurso identitário que objetivava uma união regional era menos perceptível diante de um regionalismo no qual prevaleciam disputas internas pela supremacia esportiva.

No intervalo entre o recebimento do oficio e a realização dos jogos, uma boa quantidade de notícias sobre como a Bahia deveria se organizar para o torneio foi encontrada. Com relação aos jogadores que formariam a seleção, um editorial da Semana Sportiva acreditava que "não é mister que os clubes todos contribuam. Os que não estiverem à altura de fazê-lo, que se retraiam, embora se não recusem a prestar o concurso do seu apoio e o estímulo dos seus aplausos à ideia que for vitoriosa"32. Finalmente, a revista afirmava que "nada de política! Tudo de orientação e amor às tradições esportivas da Bahia! Tudo por evitar que as glórias dos nossos dias desapareçam no torvelinho das preterições (sic) ou preferências prejudiciais"33. Além disso, o periódico também palpitava sobre a possivel escalação do time e, ainda, oferecia espaço em suas páginas para leitores que desejassem sugerir a escalação ideal.

\footnotetext{
${ }^{32}$ Semana Sportiva. Salvador, n. 66, 08 de julho de 1922.

${ }^{33}$ Idem. 
Nos gramados do Sul: a seleção baiana de futebol e o torneio do Centenário da ...

\section{O Torneio}

Com circunstâncias favoráveis à participação da Bahia no torneio e uma imprensa que, buscando resgatar as "tradições heroicas baianas", constantemente insistia na presença do estado nos festejos do Centenário, a LBDT enviou os seus jogadores ao Rio de Janeiro. Até uma festa de despedida foi organizada no Campo da Graça, a principal praça esportiva de Salvador.

Embora a imprensa fosse favorável à ida de uma seleção ao Rio de Janeiro, nem ela nem os próprios esportistas baianos acreditavam muito no sucesso do estado. Para a Semana Sportiva, os dirigentes da Liga e dos clubes "não confiarão no nosso triunfo sobre qualquer das equipes com que nos defrontaremos. Mas a certeza lhe ficará de que não pouparão esforços para dizermos, no coração do Brasil, aos campões da bola, que aqui há organização"34. Para os baianos, essa opinião encontrava respaldo nos adversários que seu time iria enfrentar: estado do Rio de Janeiro, Distrito Federal, Rio Grande do Sul e São Paulo. Acreditavam que os rivais, sobretudo os cariocas e os paulistas, eram os mestres do futebol brasileiro. A própria Semana Sportiva duvidava da "nossa vitória, sabido que os nossos irmãos cariocas são senhores do esporte bretão." Certamente a derrota era inevitável.

Obviamente, o discurso da imprensa soteropolitana revela alguma sensação de inferioridade do futebol local em comparação à realidade dos outros estados. Entretanto, esse sentimento não era exclusivo dos baianos, sendo também compartilhado pelos cariocas e paulistas quando seus clubes enfrentaram equipes de outros países consideradas superiores ${ }^{35}$. Nesse sentido, há uma associação direta entre a qualidade do futebol e o desenvolvimento material de um país ou região, revelando uma operação que estabelecia uma hierarquia entre a prática do jogo por países, regiões, estados ou cidades.

\footnotetext{
${ }^{34}$ Semana Sportiva. Salvador, n. 69, 29 de julho de 1922.

${ }^{35}$ Por exemplo, em maio de 1948, o Southampton, clube da segunda divisão inglesa, excursionou pelo Rio de Janeiro enfrentando equipes como o Fluminense, que o venceu por 4 a 0 . Apesar da vitória, a imprensa local ainda defendia a superioridade do clube, que era visto como um exemplo de civilidade e organização. Alguns relatos sobre os amistosos da equipe inglesa podem ser encontrados em: RODRIGUES FILHO, Mario. O Negro no Futebol Brasileiro. Rio de Janeiro: Mauad, 2003, p. 275.
} 
Por todo o Brasil, comparações, não só no futebol, mas em aspectos culturais e materiais, ocorreram com muita frequência, em especial na transição dos séculos XIX e XX. A proclamação da República, a abolição da escravidão e o anseio em engajar-se em uma cultura dita moderna e civilizada fizeram com que algumas cidades do país aspirassem a um novo modelo de sociedade a partir de referenciais políticos e culturais europeus. Na imprensa de Salvador, por exemplo, existiram artigos e editorais exigindo dos poderes públicos uma modernização da cidade através de reformas urbanas. Para corroborar seus argumentos, os jornais buscavam comparar Salvador a cidades europeias que tinham a sua cultura e o sistema político/econômico considerados mais civilizados ${ }^{36}$. Porém, apesar de serem referências, algumas dessas cidades também enfrentavam problemas e dificuldades estruturais e, não raramente, se encontravam longe de serem modelos de modernidade e civilidade como imaginavam alguns periódicos baianos ${ }^{37}$.

$\mathrm{O}$ que seguramente contribuiu para que os jornais e revistas soteropolitanos antevissem o fracasso da sua seleção foi uma manobra da CBD considerada muito suspeita. A princípio, o primeiro jogo da Bahia estava marcado para o dia 3 de agosto, uma quinta-feira. A seleção sairia de Salvador na terça-feira, 25 de julho, chegando à capital federal três dias depois, na sexta-feira. A CBD, então, antecipou a partida para o dia 30, no domingo, o que inviabilizaria um melhor repouso dos jogadores após uma viagem cansativa e responsável por causar enjoos em alguns deles. Além disso, a seleção baiana estaria desfalcada de dois jogadores, Popó e Santinho, que só viajaram para o Rio

\footnotetext{
${ }^{36}$ Em seu estudo, Rinaldo Leite identificou que os jornais de Salvador, ao exigirem uma inserção da cidade em uma nova cultura urbana, consideram Paris, Londres, Viena, Berlim, Roma e até mesmo Petrogrado, hoje conhecida como São Petersburgo, como cidades referências de modernidade e civilidade. Para mais detalhes, ver: LEITE, Rinaldo Cesar Nascimento. E a Bahia Civiliza-se...: ideais de civilização e cenas de anti-civilidade em um contexto de modernização urbana: Salvador, 1912-1916. Dissertação (Mestrado em História) - FFCH, UFBA, 1996, p. 40.

${ }^{37}$ Marshall Berman demonstrou como algumas cidades europeias estavam distantes de serem um modelo de modernidade. Um exemplo sintomático de Petersburgo, que curiosamente era um modelo de civilização para alguns jornais baianos. Para mais informações consultar: BERMAN, Marshall. Tudo que é sólido desmancha no ar: a aventura da modernidade. São Paulo: Companhia das Letras, 1986.
} 
Nos gramados do Sul: a seleção baiana de futebol e o torneio do Centenário da ...

de Janeiro na sexta-feira e, assim, não chegando a tempo para o primeiro jogo. Por conta disso, o Diário de Notícias publicou:

Segundo os nosso telegramas, verifica-se uma probabilidade de termos que jogar, amanhã, a partida com os cariocas, precedendo, assim ao que deliberou a Confederação, marcando-a para o dia 3 .

Uma vez resolvida a realização do nosso encontro amanhã, que esperanças poderíamos ter senão de uma formidável derrota, com a completa desorganização do nosso conjunto, que necessitará de significativa reforma, nas posições dos seus jogadores?

Estamos, entretanto, convencidos de que o chefe da nossa embaixada não concordará com semelhante desejo absurdo e prejudicial aos nossos interesses esportivos e muito menos a Liga que, neste caso, deverá preferir não concorrer a nenhum jogo a satisfazer a quem quer que seja, com o nosso absoluto prejuízo. Que abandonem o campo da luta, será mais honroso... ${ }^{38}$

Apesar da situação desfavorável, muitas surpresas ocorreram. A primeira partida dos baianos foi contra o Rio de Janeiro (Distrito Federal) que, juntamente com São Paulo, era um dos favoritos ao título. O empate por dois gols acabou frustrando os cariocas que tinham como certa a vitória contra a Bahia. Para o Diário de Notícias, "o jogo dos baianos assombrou o Rio, porque ninguém esperava que o Norte mandasse um conjunto tão harmonioso e treinado como esse" ${ }^{39}$. Os periódicos de Salvador entenderam que o empate representou mais que uma vitória. Destinando várias páginas para o grande acontecimento, a Semana Sportiva estampava: "Salve gloriosos conterrâneos: o empate de domingo valeu para nós uma admirável vitória" ${ }^{40}$. Em seguida, teceu uma análise sobre o significado daquele empate:

Mais do que a nós, baianos, infinitamente mais, o empate de domingo, no estádio do Flamengo, deve ter surpreendido aos cariocas.

Que ideia poderiam eles fazer de nós, então a de que éramos uns principiantes, apalpando agora o terreno que eles já pisavam firmes e conscientes?

\footnotetext{
${ }^{38}$ Diário de Notícias. Salvador, 29 de julho de 1922.

${ }^{39}$ Diário de Notícias. Salvador, 31 de julho de 1922.

${ }^{40}$ Semana Sportiva. Salvador, n. 70, 05 de agosto de 1922.
} 
(...) Mas os nossos guardavam em segredo, no escrínio da nossa abençoada modéstia de desprezados nortistas, as reservas do progresso e grandeza de que demos mostras às vistas, que se diriam duvidosas de que fosse verdade o que viam de 32.000 pessoas.

(...) Vivemos neste momento a grandeza desse feito e a lição inapreçável que ele representa para nós. Convençamo-nos de que na Bahia há valor, há heroísmo. A Bahia é desprezada porque nós nos encerramos aqui dentro, calados e obstinados a escurecer o que é nosso. Escapamos ao espírito ávido de aplaudir a grandeza do vizinho, a necessidade de levantar bem alto o nosso nome inconfundivelmente em todas as esferas.

A Bahia acompanha o progresso do Brasil e os seus filhos não a honram somente aqui. No coração do Brasil eles sabem dizer como agora disseram a que a nossa terra é grande entre as maiores.

Ave, irmão, que tão alto levantastes o nome da Bahia! ${ }^{41}$

Essa notícia é sintomática sobre o sentimento dos baianos em relação ao empate com os cariocas. Mesmo preocupados em "escurecer" o que era deles, existia uma vontade insuperável de mostrar para o Brasil que a Bahia não estava adormecida ou vivendo de suas glórias do passado, embora estas sempre fossem ressaltadas. O estado acompanhava o progresso do país e, portanto, deveria ser reconhecido como sempre foi: pujante e fundamental para o crescimento do Brasil. Em Salvador, o resultado foi muito festejado. "Quando foi anunciado o score de 2x2 o povo delirou. Palmas e vivas estrepitosos ecoaram, vendo-se chapéus nos ares. Uns se abraçavam com os outros, numa demonstração de intensa alegria" ${ }^{42}$. Outro texto revelador do sentimento pode ser encontrado no Diário de Noticias, quando afirma que:

O momento é de infinito júbilo, é de geral contentamento e pensamos que não deve haver um baiano, um só filho desta terra privilegiada e estremecida, que, nesta hora, não se ufane do grande feito de seus patrícios, no Rio de Janeiro.

O nosso team fatigado de uma viagem de três dias, quase sem descanso, em campo estranho e ainda desfalcado de um dos seus principais elementos de defesa, venceu, empatando com os

\footnotetext{
${ }^{41}$ Idem.

${ }^{42}$ Idem.
} 
Nos gramados do Sul: a seleção baiana de futebol e o torneio do Centenário da ...

bravos jogadores da Metrópole.

Venceu, porque abriu o score da tarde.

Venceu, porque jogou antes do dia marcado.

Venceu, porque estava com todas as circunstâncias contra o seu jogo brilhante.

Venceu, enfim, porque dominou os adversários com galhardia! Honra, portanto, a esta vitória!

Ave, heróis baianos, que salvastes os nossos foros esportivos. ${ }^{43}$

Por conta desse resultado, considerado surpreendente, gerou-se uma grande expectativa quanto aos outros jogos da seleção baiana. Houve uma relevante mobilização em dois dos principais jornais da cidade, no intuito de cobrir mais detalhadamente a participação da Bahia no torneio. O Diário da Bahia e o Diário de Noticias chegaram a montar um grande placar luminoso no centro da cidade que informaria os resultados dos próximos jogos da seleção:

O Diário de Noticias, acorrendo à ânsia com que a população espera sempre os resultados dos jogos de nosso valente scratch, ora no Sul do país, manterá toda a tarde e noite até 20 horas, um enorme placard luminoso em São Pedro, em frente ao Ponto Central, que será o acontecimento do dia.

Nesse placard serão fornecidas ao povo, de momento a momento, as notícias que nos forem chegando do desenrolar do jogo entre baianos e fluminenses, com as minúcias que o submarino nos puder trazer. ${ }^{44}$

O Diário de Noticias foi ainda mais longe ao fazer publicar uma segunda edição do seu jornal à noite para antecipar as notícias do próximo jogo dos baianos contra os fluminenses. Sobre o resultado da empreitada, o jornal publicou:

Raras vezes se tem registrado, nesta terra, um sucesso tão grande, tão pronunciado, tão eloquente, na vida de imprensa como o que coroou, ontem a nossa edição da noite.

Rodando a nossa Koëning \& Bauer às 21 horas precisas, era grande já o número de pessoas que estacionava em frente a esta redação.

Em São Pedro, aliás, na Praça Castro Alves e Baixa dos Sapateiros, a multidão aguardava, ansiosa, a chegada dos camelots.

${ }^{43}$ Diário de Notícias. Salvador, 31 de julho de 1922.

${ }^{44}$ Diário de Notícias. Salvador, 03 de agosto de 1922. 
Assim que o primeiro apareceu no ponto de secção, em São Pedro os Diários foram-lhe arrebatados em dois minutos, o mesmo se dando com os que iam surgindo.

Fato semelhante passou-se na Baixinha. Antes de onze horas, estava esgotada a edição, que excedeu às nossas melhores previsões.

Os nossos agradecimentos, pois, ao povo da Bahia. ${ }^{45}$

Tanto o placar luminoso, quanto a publicação de uma segunda edição do jornal indicam como a população da cidade estava interessada na aventura baiana nos gramados do Sul. Também não deixa de ser um sintoma de que o discurso identitário sobre a Bahia, construído pelas elites, escapava a este próprio grupo social. A seleção baiana era composta por alguns jogadores negros e populares, como Durval, Popó e Manteiga. Ao atuarem pela seleção baiana conquistando bons resultados, existia uma identificação de setores da população com esses jogadores que não necessariamente coadunava com os sentidos que as elites atribuiam ao futebol e ao Torneio do Centenário.

Após o empate contra os cariocas, o selecionado enfrentou o América, em $1^{\circ}$ de agosto, em um jogo treino vencendo-o por 2 a 1. Dias depois, em 13 de agosto, já pelo Torneio do Centenário, os baianos enfrentaram os fluminenses. Para um diário carioca que ficou admirado com a vitória da Bahia contra o América, considerado um dos times mais fortes do Rio, os "fluminenses, que têm que jogar com os baianos estão aterrorizados, tendo mandado vir de Campos seis novos jogadores, considerados os melhores do estado"46. Apesar de reforçar o time, o estado do Rio de Janeiro foi derrotado por 1 a 0 . Mais uma vez, o sucesso da seleção baiana inspirou os jornais de Salvador a escrevem extensos editorais efusivos comentando o significado daquela vitória:

Nem se diga, senhores, nem se articule, nem se discuta, nem se ouse afirmar que tal coisa pouco vale, porque o foot-ball é fútil e não deve ser levado a sério.

Nesta hora de progresso do mundo deve ser inacreditável que, numa terra que se diz civilizada, haja alguém que pretenda assim qualificar o admirável e necessaríssimo esporte bretão,

${ }^{45}$ Diário de Notícias. Salvador, 04 de agosto de 1922.

${ }^{46}$ Diário de Noticias. Salvador, 02 de agosto de 1922. 
Nos gramados do Sul: a seleção baiana de futebol e o torneio do Centenário da ...

praticado hoje em todo o orbe e pelo qual as multidões mantêm supremo interesse, reconhecendo-lhe a utilidade, na educação fisica do cidadão.

O foot-ball, longe de ser uma simples brincadeira, longe de ser um mero bate-bola, é uma escola de bravura, de destemor, de valentia, de audácia, e constitui, por assim dizer, aquilo a que um grande escritor brasileiro chamava de base fisica da coragem.

Sobre essa base é que se assentarão, amanhã, os talvez imortais defensores do nome do Brasil, quando este, nas suas horas amargas de provação, tiver de desafrontar os brios conculcados, num campo de guerra inevitável.

Heróis, portanto, não são os somente, os que derramam o sangue pela Pátria, nas lutas verazes, contra inimigos de ferro e fogo.

Não são somente os que sacrificam a vida, para feitos assombrosos.

São, modestamente, embora, os que, como os nossos jovens conterrâneos, saem de sua terra, sob a expectativa geral de um desastre para os nossos foros de esportistas, e, fazendo prodígios de força, num meio zombeteiro e achincalhante, conseguem eletrizá-lo com triunfos inauditos, cercando, pelo menos nisto, o nome da Bahia, de admiração e respeito.

Eis aí porque um pontapé de Popó ou de Durval tem, nesta hora, o valor de heroísmo.

Esses ponta-pés estão fazendo a legítima propaganda do progresso de nossa terra, pondo-a ante a embasbacada estupefação do Sul, muito acima do plano em que ela pairava, coberta de moteios. ${ }^{47}$

Esse editorial apresenta de maneira evidente qual o sentido atribuído pela imprensa ao futebol. Enquanto uma atividade considerada fundamental para o fortalecimento fisico e moral da sociedade, os jornais consideravam imprescindivel que a Bahia não ficasse fora desse processo. Principalmente após a Primeira Guerra Mundial, as práticas esportivas foram encaradas pelas elites intelectuais como necessárias para a inserção da sociedade em uma dinâmica de engajamento físico de desenvolvimento do corpo, de regeneração racial, assumindo, portanto, um

\footnotetext{
${ }^{47}$ Diário de Notícias. Salvador, 04 de agosto de 1922.
} 
caráter eugênico, pedagógico e até militar ${ }^{48}$. A guerra contribuíra para essa dimensão dos esportes, visto que, para Nicolau Sevcenko, "também nesse contexto é que as atividades atléticas tiveram o seu boom, compreendidas como um segredo militar para a adequada preparação das tropas"49.

Nesse sentido, as vitórias da seleção baiana são um demonstrativo incontestável de que o estado tinha condições de produzir homens mental e fisicamente fortes que teriam utilidade para o Brasil em um momento de necessidade. Enfim, a vitória contra os fluminenses servia para afirmar que na Bahia existia progresso físico, social e moral que não deveria ser desperdiçado em detrimento de bairrismos fundamentados na defesa de que a força do país estava exclusivamente no Sul. Enfim, no Torneio do Centenário, as elites baianas, mais do que a busca pelo fortalecimento de uma identidade assentada no heroísmo, na grandeza ou na tradição, também passaram a reivindicar por uma participação mais ativa nos destinos da nação.

Pelo que consta, os esportes eram apenas mais um dos espaços encontrados pelas elites baianas para a retomada de uma centralidade do estado no cenário nacional. Existem estudos que demonstram como a Bahia, em esferas como a literatura, ainda no século XIX, buscava se inserir de maneira proeminente na ideia de nação que se formava ${ }^{50}$. Na política institucional, também encontramos lutas por um espaço privilegiado. No mesmo ano do Centenário, por exemplo, o estado era um dos pilares de um movimento político denominado de A Reação Republicana. Tratava-se de uma articulação entre a Bahia, o Rio de janeiro, o Distrito Federal e Pernambuco que visava a tomar o poder da coligação São Paulo/Minas Gerais, montando uma chapa com Nilo Peçanha e José Joaquim Seabra ${ }^{51}$. Inclusive, após o empate da seleção baiana com os cariocas, "a multidão

\footnotetext{
${ }^{48}$ Sobre o papel do esporte na formação de uma cultura do engajamento físico, ver: SEVCENKO, Nicolau. Orfeu extático na metrópole: São Paulo: sociedade e cultura nos frementes anos 20. São Paulo: Companhia das Letras, 1992.

${ }^{49}$ SEVCENKO, Nicolau. Futebol, metrópole e desatinos. Revista USP, São Paulo, n.22, jun/ ago. 1994, p. 33.

${ }^{50}$ ALVES, Lizir Arcanjo. Os tensos laços da nação: conflitos político-literários no Segundo Reinado. Tese (Doutorado em Letras) - Salvador, 2 v. Instituto de Letras, UFBA, 2000.

${ }^{51}$ Sobre a Reação Republicana: FERREIRA Marieta de Moraes. A Reação Republicana e a Crise dos Anos 20. Estudos Históricos, CPDOC/FGV-RJ, vol. 6, n. 11, 1993.
} 
Nos gramados do Sul: a seleção baiana de futebol e o torneio do Centenário da ...

em delírio percorreu as principais ruas, ovacionando os jogadores baianos, tendo seguido até o palácio, para cumprimentar o governador Dr. J. J. Seabra"52.

A campanha da seleção baiana não só empolgou a imprensa e a população da cidade. Os dirigentes esportivos que estavam na cidade organizaram uma passeata em comemoração aos resultados no torneio. Idealizada pelo presidente da LBDT, Medeiros Netto, o cortejo, que contava com torcedores de vários clubes e vários automóveis com senhorinhas e personalidades políticas, saiu do Largo do Terreiro, passou pela Avenida Sete, encerrando o seu itinerário na sede do Botafogo, importante clube da cidade, que ficava no primeiro andar de um edificio nas Mercês, no centro de Salvador. Na sacada do prédio, alguns oradores se revezaram discursando sobre os feitos da Bahia na capital federal. Segundo o Diário de Notícias, o próprio Medeiros Netto disse algumas palavras que foram lembradas pelo jornal:

Pensando do mesmo modo pelo qual nos manifestamos, nas nossas edições de anteontem e ontem, que o foot-ball não é uma futilidade, como alguns entendem, o orador entrou de tecer considerações confirmadoras dessa assertiva, demonstrando o valor desse jogo como escola de educação moral, física e cívica, e, batendo-se pela necessidade dos governos protegerem-no, nas sociedades, como a nossa, em formação, uma vez que um bom sportman é sempre um excelente cidadão instruído, forte na sua compleição fisica, e capaz, de mais tarde, em campos mais vastos, onde move em holocausto, em defesa da Pátria, se bater pela sua bandeira, como nos dias da paz pugna valorosamente, em prol do pavilhão do seu club esportivo. ${ }^{53}$

Após os resultados contra os cariocas e fluminenses, a Bahia ainda venceu o Rio Grande do Sul pelo placar minimo e, finalmente, enfrentou São Paulo, obtendo a sua única derrota no certame pelo placar de 3 a 0 . Diante da vitória contra os gaúchos, novamente a imprensa não tardou em elogiar o selecionado baiano, exaltando as chamadas "tradições heroicas

52 “Na Bahia, uma grande multidão felicitou o Sr. Presidente do Estado por motivo do empate bahianos x cariocas". O Imparcial, 31 de julho de 1922, apud MALIA, João. Jogos Olympicos do Rio de Janeiro no Centenário de 1922: olhares sobre a política de um projeto de unificação e celebração da nação através do esporte. ANPUH. Anais do XXVI Simpósio Nacional de História. São Paulo: USP, 2011.

${ }^{53}$ Diário de Notícias. Salvador, 05 de agosto de 1922. 
baianas". A Semana Sportiva declarou que "o entusiasmo transborda do intimo para essa exclamação de triunfo: Viva a Bahia! Viva a Bahia, sim a terra heroica em todos os tempos! Viva a Bahia! Sim, a gloriosa de sempre!"54. Até mesmo a derrota contra os paulistas foi minimizada. Para os jornais de Salvador e de outras cidades, São Paulo contava como o melhor jogador do Brasil no momento, Artur Friedenreich, responsável pelo terceiro gol do jogo ${ }^{55}$.

Os paulistas foram os campeões do certame, vencendo todas as suas partidas, enquanto baianos e cariocas ficaram empatados em segundo lugar, com o mesmo número de pontos. Terminada a missão vitoriosa no Sul, rapidamente a imprensa soteropolitana tratou de resumir o significado da campanha da sua seleção. Vale a pena ler trechos de um editorial da Semana Sportiva que afirmava:

Aí vêm eles, os triunfadores! Aî vêm eles, o que partiram sob as atmosferas de presságios, de maus presságios. Aî vêm eles, os que, surpreendendo mesmo a nós que os conhecemos, souberam tirar da fonte inexaurivel de reservas, que só possuem os heróis, os recursos assombrosos de energia e resistência que esta hora os sagram aos nossos olhos.

(...) Marcharam para a derrota, tanto os amedrontaram os pregoeiros da fama dos nossos irmãos do Sul e voltam laureados!

Não são uma legião de soldados que voltam de abater o inimigo, à sombra poderosa do pavilhão pátrio, esses que a Bahia estreitará dentro em pouco nos seus braços de mãe amantíssima.

Isso eles provaram que serão amanhã, no momento, que Deus afaste dos nossos horizontes, em que se lhes reclamarem os serviços de patriotas educados na escola sadia da cultura física.

Eles voltam de um certame, onde se empenharam com irmãos, que falam a mesma lingua e vivem sob o fulgor do mesmo céu.

Mas, há um ponto que obriga a por em relevo a significação das vitórias alcançadas.

É injustamente a propalada supremacia do Sul sobre o Norte!

\footnotetext{
${ }^{54}$ Semana Sportiva. Salvador, n. 71, 12 de agosto de 1922.

${ }^{55}$ Arthur Freidenrich foi um dos maiores jogadores do início do século XX. Sobre o jogador, sugiro: JUNIOR, René Duarte Gonçalves. Freidenreich e a reinvenção de São Paulo futebol e a vitória na fundação da metrópole. Dissertação (Mestrado em História) - FFLCH, USP, 2008. 
Nos gramados do Sul: a seleção baiana de futebol e o torneio do Centenário da ...

Nisso, no adiantamento da cultura física, no foot-ball, nós éramos tidos como afamados campões de aldeia. Desmentiram-se os interessados nessa propaganda.

(...) Como os receberemos nós? O futuro não nos perdoaria pelas vozes das outras mocidades que se vão formando a nossa indiferença à passagem dos que nos souberam elevar e engrandecer!

Eles aí vêm! Que todos convirjam para um só fim: o brilho da sagração! ${ }^{56}$

Assim como o Diário de Noticias, de modo inequívoco, o editorial da Semana Sportiva defendia que o bom desempenho dos baianos no esporte é um indicativo de que não só o Sul é capaz de conduzir o Brasil rumo ao progresso físico e social. Mesmo a favor da unidade da pátria, os jornais da cidade queriam destacar a contribuição da Bahia, assim como os outros estados também reivindicavam algum tipo de centralidade politica, cultural ou social na formação da nacionalidade brasileira. Enfim, as vitórias do estado traduzem a necessidade dos baianos em serem reconhecidos e terem, por meio do esporte, um espaço legítimo nos destinos da nação como, segundos os próprios, sempre tiveram em outros momentos da História do Brasil.

\section{O retorno dos baianos: repercussões...}

Como não poderia deixar de ser, a recepção aos jogadores foi bastante calorosa e muito bem planejada. Logo após o jogo contra os fluminenses, o Diário de Notícias já liderava a organização de uma comissão que seria responsável pela recepção aos jogadores. O diário pensava que:

(...) a Bahia que tanto há vibrado de entusiasmo até aqui, pelas vitórias magnificas de seus filhos, no Rio, não deve deixar passar despercebida a volta desses bravos, do Sul da República.

Lembra, portanto, algumas homenagens a serem prestadas aos nossos valentes foot-ballers, uma das quais deve ser o oferecimento a cada um dos elementos componentes do nosso scratch em nome do povo baiano, de uma linda medalha de ouro, com brilhante, como lembrança das vitórias alcançadas contra os sulistas em nome deste estado.

\footnotetext{
${ }^{56}$ Semana Sportiva. Salvador, n. 71, 12 de agosto de 1922.
} 
Outra homenagem a ser prestada ao destemerosos patrícios será a imponente recepção que se lhes deve fazer, organizando-se um cortejo-monstro que desfile pela Avenida Sete de Setembro. ${ }^{57}$

Para que a recepção fosse bem sucedida, o jornal iniciou uma campanha de doação para a compra de medalhas, flores e outros adereços ornamentais, arrecadando 1:970\$000. Praticamente todos os dias, desde a publicação da proposta de formação de uma comissão, o Diário de Notícias estampava nas suas páginas o andamento da campanha donativa. Diversos valores foram doados, tanto de forma individual quanto coletiva. Vale destacar que entre os $100 \$ 000$ doados por alguns doutores e personalidades públicas, existiam pequenas quantias como a de $\$ 500$ doados por um operário ou $5 \$ 000$ e $20 \$ 000$, respectivamente doados por operários marmoristas e empregados da empresa Fratelli Vita, o que indica a vontade desses sujeitos, ao seu modo, de participarem dos festejos em homenagem aos jogadores.

Inclusive, o próprio Diário de Noticias estimulava a participação da população na recepção aos jogadores, publicando em suas páginas avisos conclamando todos:

A Comissão Central, aclamada na grande assembleia esportiva de 11 do corrente, reunida na sede do Botafogo Sport Club, vem, por este meio, lançar um apelo ao povo baiano, sem distinção de classes no sentido de serem prestadas aos nossos dignos conterrâneos e valentes foot-ballers do scratch, que tão brilhantemente representaram a Bahia nos jogos de seleção, realizados no Sul do pais, as merecidas homenagens a que eles fizeram jus, elevando a grandes alturas os créditos esportivos deste estado. ${ }^{58}$

Em várias edições dos principais jornais da cidade, figura um aviso de grandes proporções, com o título "Ao Povo", contendo os dizeres: "ide ao desembarque dos nossos valorosos players! Senhoras e senhorinhas ide ao stadium, franqueado a todos, aguardar a chegada do préstito esportivo"59. Até mesmo um pedido para que o comércio fosse fechado foi feito pelo jornal, em uma tentativa de fazer da chegada dos jogadores uma

\footnotetext{
${ }^{57}$ Diário de Notícias. Salvador, 04 de agosto de 1922.

${ }^{58}$ Diário de Notícias. Salvador, 17 de agosto de 1922.

${ }^{59}$ Idem. 
Nos gramados do Sul: a seleção baiana de futebol e o torneio do Centenário da ...

apoteose. Em um dos apelos mais contundentes, recorre-se à ideia de uma identidade mais fortalecida caso o comércio encerrasse suas atividades para que os seus empregados acompanhassem a recepção à seleção baiana:

Há em jogo, como bem diz a Comissão Central, no seu apelo ao comércio, além do lado de natural satisfação dos nossos sportmen, pelas vitórias de seus companheiros, qualquer coisa do amor próprio de todos os baianos, que se ufanam de ter visto o nome e as cores de seu estado, valentemente defendidos e belamente triunfantes em contendas com as representações de vários outros Estados da Federação. Que é isto, senão a base lógica do civismo, do civismo que se desenvolve por intermédio do esporte e que se tornará acendrado em pugnas que implicarem a soberania da nossa terra ou da nossa Nação?

Nada mais natural, portanto, do que atender o comércio ao pedido da digna Comissão Central, que, diga-se a verdade, sintetiza e exprime, inquestionavelmente a vontade geral. ${ }^{60}$

A proposta da comissão era a realização de um denominado cortejo-monstro que, com mais de cinco quilômetros de percurso, sairia do cais do porto, passando pelas Ruas Conselheiro Dantas e Santa Barbara; Ladeira da Montanha; Praça Castro Alves; caminharia toda Avenida Sete até o largo da Vitória; seguiria pela Rua da Graça até a chegada no largo homônimo; e, finalmente, prosseguiria pela Avenida Euclides da Cunha, quando chegaria ao Campo da Graça na esquina com a Rua Catarina Paraguaçu. No estádio, os jogadores seriam recebidos e ouviriam o discurso de alguns oradores, além de receberam medalhas e outros mimos.

De fato, a chegada dos jogadores, em 24 de agosto, um mês após deixarem Salvador, foi apoteótica. De acordo com o Diário de Notícias, "o cais já estava apinhado, podendo-se calcular a multidão em cerca de quatro mil pessoas. Descrever o que foi a acostagem da lancha ao cais é impossível, tal o delírio do povo, que arrebatou nos braços os seus queridos jogadores" ${ }^{\text {. }}$.

Segundo alguns diários, foi possivel contabilizar cerca de cento e cinquenta e nove carros que compuseram o cortejo. Durante o itinerário, o Diário de Notícias lembrou que "galgada a

${ }^{60}$ Diário de Notícias. Salvador, 21 de agosto de 1922.

${ }^{61}$ Diário de Notícias. Salvador, 25 de agosto de 1922. 
Montanha, continuou o entusiasmo no Largo do Teatro, tendo nas Mercês sido jogadas flores nos scratchmen"62. A surpresa do cortejo foi uma parada não programada em frente à sede de um dos mais populares clubes de Salvador, o Ypiranga, na Avenida Sete, nas Mercês. Nesse momento, na sacada do edificio, "a interessante menina Esther Helenita de Freitas pronunciou entusiástica alocução, dita com muita naturalidade que agradou geralmente"63. Eis alguns trechos do discurso:

Valorosos patrícios meus!

O meu peito juvenil ainda freme de entusiasmo aos feitos vossos, como igualmente, multidão daqui e d'além em incontidos ímpetos de verdadeira consagração comentaram a glória da vossa vitória.

Soubeste com acrisolada abnegação elevar bem alto o nome da Bahia esportiva no seio da Federação Brasileira onde os seus sportmen são verdadeiros campeões nacionais.

(...) Firmastes com segurança de convicção a grande parcela da Bahia, como potência máxima na formação do engrandecimento moral do nosso amado Brasil.

Assim, se não sois verdadeiros heróis pela natureza dos feitos em apreço, sois com admiração de todos nós, abnegados e valorosos representantes genuínos da Bahia fisica. ${ }^{64}$

Duas horas após o desembarque no cais, os jogadores chegaram, às 18 horas, no Campo da Graça, onde foram recebidos por várias senhoras que já os aguardavam no estádio, sendo responsáveis pela colocação das medalhas neles.

\section{À guisa de conclusão}

Em paralelo à recepção apoteótica dos jogadores, a imprensa de Salvador não deixou de criticar a CBD, bem como polemizar com alguns jornais cariocas considerados defensores da entidade que dirigia os esportes no país. A Semana Sportiva, em um texto escrito antes do retorno dos baianos, ressaltava as qualidades da Bahia sem se esquecer dos descasos da Confederação na organização do Torneio do Centenário:

\footnotetext{
${ }^{62}$ Idem.

${ }^{63}$ Idem.

${ }^{64}$ Idem.
} 
Nos gramados do Sul: a seleção baiana de futebol e o torneio do Centenário da ...

Engalana-te, oh! Bahia, para receber em teus braços carinhosos os filhos estremecidos que tanto elevaram o teu nome, sabendo honrar as tuas tradições.

Com o coração a palpitar, a Bahia acompanhou os lances empolgantes deste scratch vencedor, com os olhos d'alma fitos em todos os movimentos desta embaixada que se glorificava.

Desprezando por completo a ação despeitada da Confederação, convertendo o campeonato em treinos quando ganhávamos, ora contando pontos, ora classificando de mero ensaio e prova de seleção, modificando datas, alterando o número de partidas, obrigando a jogarem com o quadro desfalcado e jogadores doentes, esta foi a primeira recepção à embaixada ao chegar ao Rio, e tudo isto para não levarmos a vitória que tão galhardamente obtivemos.

E agora que a embaixada regressa triunfadora, e a Bahia, que ainda sente os estremecimentos de suas emoções com os braços abertos recebe forasteiros, a seus filhos gloriosos engalanada, com toda efusão d'alma em delírio de contentamento, recebe-os vitoriosos - parodiando Roma, ao receber os seus generais - à nossa embaixada conquistadora e glórias a Bahia beija-lhes as frontes, cingindo-as de loiros. Estão glorificados.

E sejam bem vindos ao seio amorável da idolatrada Bahia.

Salve, campeões! ${ }^{65}$

Além dessas críticas, o semanário, em tom de denúncia, ainda lembrou que o descaso da CBD pela Bahia revelou-se até no transporte oferecido aos seus jogadores para o retorno a Salvador. De acordo com a revista, "atiraram os nossos players para os camarotes ingratos de um dos piores paquetes do Lloyd, o Iris, que lá esteve entre o Rio e Vitória num arrastar-se que as nossas carroças não invejariam"66. O texto encerrou lembrando que "fique a lição, bem sincera e comprovadora do caso que se liga, na CBD, aos estados do Norte" 67 .

Podemos considerar que as críticas da imprensa baiana à CBD estão dentro de um contexto de recrudescimento das tensões na relação entre a Bahia e o Rio de Janeiro. Isso fica explícito se investigarmos o comportamento de alguns jornais cariocas em relação à campanha da Bahia no Sul. Não foram

\footnotetext{
$\overline{{ }^{65} \text { Semana Sportiva. Salvador, n. 71, } 12 \text { de agosto de } 1922 .}$

${ }^{66}$ Semana Sportiva. Salvador, n. 73, 26 de agosto de 1922.

${ }^{67}$ Idem.
} 
poucas as vezes que os periódicos de Salvador publicaram notícias de como alguns diários da capital federal subestimavam o desempenho dos baianos, minimizando suas vitórias. Quando a Bahia derrotou o Rio Grande do Sul, o Diário de Notícias publicou uma matéria de título "A nossa vitória e o despeito dos jornais cariocas", que listava um resumo das chamadas de alguns diários do Rio comentando o feito dos baianos. Segundo o Diário de Notícias:

O Jornal do Brazil, torcedor ridículo dos cariocas, reconhece, todavia, que o shoot de Petiot, que conquistou o goal, foi prodigioso.

O Jornal do Comércio noticia a vitória baiana friamente, parecendo sofrer a humilhação dos jogadores locais, considerados iguais aos campeões do Norte.

Digam o que disserem, o povo é o verdadeiro e maior juiz que existe em foot-ball e consagrou os baianos. A colônia baiana festejou o triunfo. ${ }^{68}$

Aliado a esses pequenos comentários, existiu um episódio mais significativo que indica em que altura estava a relação entre a imprensa de Salvador e a do Rio. Quando os jogadores baianos voltavam para sua terra natal, o paquete Iris quebrou e, por conseguinte, teve que atracar em Vitória, no Espírito Santo, para reparos. Aproveitando o ensejo, alguns jogadores que se encontravam naquela cidade convidaram a seleção baiana para a disputa de um amistoso, cujo resultado foi uma estrondosa goleada dos baianos de 8 a 0 . Evidentemente, o resultado, para os diários de Salvador, foi mais um atestado do "heroísmo" da Bahia. No entanto, para o jornal O Paiz, do Rio de Janeiro, o jogo foi:

(...) apenas um bate-bola, que serviu mais uma vez para a garganta baiana dar saída à sua incomensurável basofia, basofia de que se fizeram ecos os jornais da terra do vatapá, por ocasião dos encontros feridos aqui e em S. Paulo, sobre os quais os cronistas de São Salvador fantasiaram coisas retumbantes, piramidais.

Aqui no Rio, diz-se de um individuo potoqueiro e afeito a hespanholadas, que ele é vendedor do angu; ora, sendo a Bahia pátria por excelência do angu, com e sem caroço, não se deve

${ }^{68}$ Diário de Notícias, Salvador, 11 de agosto de 1922. 
Nos gramados do Sul: a seleção baiana de futebol e o torneio do Centenário da ...

estranhar a pretensão do chefe da embaixada daquele estado, quando quis impingir a sua mercadoria aos jornais, por via telegráfica. ${ }^{69}$

Percebe-se que o colunista do O Paiz considera que não só no jogo contra os capixabas, como também em toda a campanha dos baianos na capital do Brasil não houve nenhuma excepcionalidade, existindo sempre a pretensão de superioridade da Bahia. Não passou despercebido o preconceito do colunista carioca ao se utilizar das expressões "terra do Vatapá" e "Pátria do Angu” para caracterizar o estado ${ }^{70}$. Como era de se esperar, tal ofensa não ficou sem resposta:

Prefeririamos não comentar essa grossa estupidez, reveladora de não menos grossa inveja mal ferida, mas preciso é que ponhamos agora, os pontos nos $i$.

Os baianos devem ser o que o suculento missivista supra-afirma (sic) porque não confundem com os capadócios de lá.

Instados a que jogassem em Vitória, para não parecerem o que alguns locais se afiguraram acenderam fidalgamente, ao convite, sem preocupações de triunfo ou de derrota. Jogaram e bateram os espírito-santenses pelo formidável score de 8x0.

Isto era positivamente intolerável, principalmente pelos fatos anteriores que puseram os nossos acima de quantos cariocas, fluminenses e gaúchos mais pintados lhes apareceram pela frente. Toca, portanto, a insultar a Bahia. Agora somos vendedores de angu, cheios de basofia, pretensiosos, potoqueiros, o diabo a quatro.

Que querem? Surramos vergonhosamente os gloriosos capixabas, surramos fluminenses e gaúchos, com vantagem surramos os leaders da pebolistica metropolitana, impondo-lhe um empate, por favor, e, portanto, não valemos nada...

Será conveniente, entretanto, que a Liga Bahiana arquive mais esta lição, sem caretas, para que, quando receber novo e delicado convite dos sabichões, a fim de tomar parte em Olimpiadas ou provas de seleção, posso mandá-los imediatamente plantar batatas...

Será mais pratica e menos desagradável para todos nós... ${ }^{71}$

\footnotetext{
${ }^{69}$ Diário de Notícias. Salvador, 31 de agosto de1922.

${ }^{70}$ Gilberto Freyre identificou que, nos jornais sulistas, uma das formas de estigmatizar a Bahia associando-a a uma cultura negra e, consequentemente, "atrasada" era representá-la caricaturalmente por uma baiana gorda, de turbante e fazedora de angu. FREYRE, Gilberto. Ordem e progresso. São Paulo: Global Editora, 2004, p. 162.

${ }^{71}$ Diário de Notícias. Salvador, 31 de agosto de 1922.
} 
Seja nas posturas da CBD ou nas desavenças entre imprensa soteropolitana e carioca, o que estava posto era que, gradativamente, o Norte passou a reivindicar uma maior participação nos destinos do esporte nacional. De um lado, percebemos a emergência esportiva dos baianos, pernambucanos ou paraenses buscando um espaço na construção de uma identidade nacional pelo futebol e, do outro, determinados grupos sociais do Rio de Janeiro, muitas vezes legitimados pela imprensa local, tentavam conter esse processo num esforço de manutenção de uma centralidade e protagonismo sulista.

Enfim, observando a presença do esporte baiano nas festas na capital federal, aqui discutida desde os seus antecedentes até o certame propriamente dito, é possivel entender que o Torneio do Centenário se apresentou como uma oportunidade para a Bahia repensar e reivindicar a sua inserção no processo de construção de uma identidade nacional, oportunizada pelo gradativo envolvimento do futebol na nacionalidade brasileira. Já na década de 1920, o jogo fomentava identidades mais amplas, não necessária e exclusivamente ligadas a uma classe ou a um grupo. Um exemplo pode ser observado na conquista do Brasil do III Campeonato Sul Americano de 1919, realizado no Rio de Janeiros. A vitória foi noticiada entusiasticamente por diversos jornais do Brasil como um demonstrativo da força do país ${ }^{72}$. O envolvimento dos esportes, sobretudo do futebol, nas festas do centenário, é um indício de como a prática possibilitava para o país a reflexão sobre uma identidade nacional.

No andamento desses processos, a postura da imprensa baiana em exigir da LBDT a participação no torneio a qualquer custo, vibrar efusivamente com o sucesso e até considerar um empate com os cariocas uma grande vitória revelam como a Bahia estava a par desse contexto, buscando um espaço legítimo nele.

A tentativa de inserção do estado na construção de uma identidade nacional por meio do esporte, para as suas elites e dirigentes esportivos, parecia encontrar um forte empecilho na

\footnotetext{
${ }^{72}$ Sobre o III Campeonato Sul Americano e os seus desdobramentos, conferir: PEREIRA, Leonardo Affonso de Miranda. Footballmania: uma história social do futebol no Rio de Janeiro, 1902-1938. Rio de Janeiro: Nova Fronteira, 2000.
} 
política esportiva da CBD. Ao planejar o Torneio do Centenário de modo que prejudicasse a participação dos estados do Norte, a Confederação matinha uma política considerada pela imprensa soteropolitana explicitamente bairrista, privilegiando os estados do Sul73, especialmente Rio e São Paulo.

Diante do comportamento da CBD e das reações a ele, podemos indagar o quanto nacional a Confederação pretendia ser no que tange à sua política esportiva. No final, o torneio revelou uma tensão estabelecida entre os estados do Norte e a CBD. De um lado, uma busca da região por uma legitimidade na construção de uma identidade nacional a partir do futebol e, do outro, a política da Confederação. Ao que parece, no momento em que o Brasil festejava e refletia sobre sua condição de nação, o esporte surgia como uma possibilidade de congraçamento. O problema é que as tensões regionais insistiam em permanecer e se ressignificar na formação da nação brasileira.

Outra conclusão não menos importante é que, para além do discurso das elites baianas, que perceberam no futebol uma possibilidade de afirmação identitária do estado e retomada do seu prestígio no cenário nacional, a população subalternizada e negra de Salvador também se reconhecia não seleção baiana, muito embora seu elo de identificação passasse ao largo do sentido do futebol forjado pela imprensa e pelas elites locais. $\mathrm{O}$ interesse popular em acompanhar diariamente a campanha dos seus patrícios, esgotando, rapidamente, as edições dos jornais, bem como participar das homenagens feitas aos jogadores doando pequenas quantias para a comissão formada para recepcionar os atletas são evidências disso.

Há outros episódios do futebol baiano em que é possivel compreender como as camadas populares formularam a partir do esporte uma identidade própria. Em 1921, por exemplo, o mesmo América que perdeu para os baianos no Rio de Janeiro visitou Salvador enfrentando e vencendo praticamente todos os clubes locais. Diante de um vexame que se anunciava, foi organizado, pelo esportista Benjamim Bompet em conjunto com

\footnotetext{
${ }^{73} \mathrm{Na}$ década de 1920, não existia uma divisão regional com o sudeste e o nordeste como entendemos.
} 
uma sociedade de cor Henrique Dias74, um time homônimo, composto apenas por negros, que venceu a equipe carioca por um placar elástico. Dias após o grande feito, um editorial da Semana Sportiva logo tratou de comentar o sucesso da equipe, reconhecendo o valor e a importância dos negros baianos, não só no futebol, como na própria História do Brasil, uma vez que "nas pequenas como nas grandes coisas é sempre a raça negra quem da nota em nosso país. Esta é que é a verdade. Senão vejamos as glórias do nosso exército e da nossa marinha a quem mais devemos"75. Todavia, para o semanário, o único problema dos jogadores residia no fato de eles serem "infelizmente e unicamente da raça negra"76.

Nesse caso, é inequívoca a tentativa de elogiar os jogadores negros numa operação de identidade que, apesar de reconhecer o feito e a relevância deles para o futebol e História da Bahia, mantinha, a partir de um discurso racializado, legitimado pelo contexto de ideologia eugênica, um lugar de subalternidade para os negros, quando da afirmação de que o único problema era a raça à qual pertenciam.

Por outro lado, algumas fontes indicam que a vitória do time Henrique Dias, mais do que uma prova da força da Bahia, como as elites entendiam e queriam, foi uma demonstração de afirmação de uma identidade racial, isto é, um atestado de importância dos negros para o estado, como pode ser observado em uma nota divulgada pelo secretário da sociedade de cor informando que "A Liga Henrique Dias vai oferecer sponte sua as

\footnotetext{
${ }_{74}$ Não encontramos muitos dados sobre esta entidade. Jeferson Barcelar encontrou referências dela no Jornal Democrata em 21 de março de 1917. Outra referência à Liga foi encontrada em Thales de Azevedo. Todavia, este autor identificou a fundação de uma Liga Henrique Dias, em 1937, o que sugere que a entidade organizada naquele ano poderia ter alguma relação com a anterior. Sobre esta entidade, Thales atentou que, de acordo com os seus estatutos, ela tem como finalidades pugnar pelo congraçamento e união entre pessoas de cores epidérmicas diferentes, desenvolver a educação, principalmente dos associados e suas famílias, dar-lhes assistência, realizar diversões, praticar esportes e comemorar datas cívicas. Sobre: AZEVEDO, Thales de. As elites de cor numa cidade brasileira: um estudo de ascensão social \& classes sociais e grupos de prestígio. Salvador: EGBA/EDUFBA, 1996, p. 158; BACELAR, Jeferson. A hierarquia das raças: negros e brancos em Salvador. Rio de Janeiro: Pallas, 2001, p. 144.
}

${ }^{75}$ Semana Sportiva, Salvador, n. 35, 03 de dezembro de 1921.

${ }^{76}$ Idem. 
Nos gramados do Sul: a seleção baiana de futebol e o torneio do Centenário da ...

medalhas, como homenagem ao valor dos homens de cor da nossa terra" 77 .

Enfim, seja nesse episódio ou na campanha da Bahia no Torneio do Centenário, é preciso ter em mente que na tentativa de se pensar o futebol como um elemento de afirmação identitária com propósitos diversos, não devemos levar em consideração somente a imprensa e as elites que produziam um discurso, mas, sobretudo, quem agenciava este, ressignificando-o e reivindicando uma participação legitima nele. Assim, se os periódicos de Salvador reconheciam na seleção baiana e na sua campanha no Rio de Janeiro a importância do estado para o Brasil, os negros e populares baianos também reconheciam o papel e o valor dos seus pares na própria seleção conquistando, ao seu modo, um lugar legítimo na construção de uma identidade baiana pelo futebol.

Resumo: Este artigo pretende perceber como a participação e o desempenho da Bahia, no I Campeonato Brasileiro de Seleções ou no Torneio do Centenário, em 1922, representaram uma oportunidade para o estado reivindicar uma centralidade na construção de uma identidade nacional associada ao futebol. O Torneio foi idealizado enquanto seletiva para a formação de uma seleção brasileira que disputaria o VI Campeonato Sul Americano no Brasil. Além disso, o evento também passou a ser identificado como parte da comemoração ao I Centenário da Independência, uma data que oportunizou ao país refletir sobre sua identidade nacional, bem como repensar sua inserção na modernidade. A Bahia obteve um bom desempenho no certame, assegurando a segunda colocação. Consequentemente, a imprensa local passou a reivindicar a participação dos seus atletas na seleção brasileira, criticando o menosprezo de Rio e São Paulo para com os estados do Norte e, principalmente, questionando a política esportiva da Confederação Brasileira de Desportos, a CBD, muito voltada para os estados do Sul. Ademais, a campanha vitoriosa, para as suas elites, constitui-se em um aspecto representativo de força e da grandeza dos baianos, o que os credenciava a reclamar, a partir do esporte, por um maior espaço e protagonismo nos destinos do país. Finalmente, a campanha da Bahia e os seus desdobramentos nos permitiram problematizar os limites

$\overline{77}$ Jornal Diário de Notícias. Salvador, 3 de fevereiro de 1922. 
e peculiaridades da construção de uma identidade nacional pelo esporte, no momento em que o país buscava repensar sua identidade historicamente marcada por disputas e tensões regionais.

Palavras-chave: Futebol. Bahia. Identidade. Centenário da Independência.

Abstract: This article aims to understand how the participation and performance of the state of Bahia at the I Campeonato Brasileiro de Seleções (I Brazilian Soccer Championship), also known as the Torneio do Centenário (Centenary Championship) in 1922 represented an opportunity for the state to claim a centrality in the formation of a national identity associated with soccer. The tournament was conceived as a draft for the formation of a national soccer team that would participate in the VI Campeonato Sul Americano (VI South American Championship) in Brazil. In addition, the event also came to be regarded as a celebration of the first centenary of the Independence, a date that has encouraged the country to reflect upon its national identity, as well as to reconsider its insertion in modernity. Bahia did well in the tournament, ensuring the second position. As a result, the local press went on to claim the participation of their athletes in the national team and to criticize the disregard of the states of Rio de Janeiro and São Paulo towards the Northern region of the country. The local press would also challenge the policies of the Confederação Brasileira de Desportos (Brazilian Sports Confederation), the CBD, claiming that they favored the Southern states. Moreover, for the local elites the success of Bahia in the tournament represented the strength and greatness of the state, which gave them the right to claim a greater space and role in the destiny of the country. Finally, the performance of Bahia and its consequences have allowed us to question the limits and peculiarities of the formation of a national identity through the sport, at a moment when the country sought to rethink their identity historically marked by disputes and regional tensions..

Keywords: Soccer. Bahia. Identity. Centenary of Independence.

Artigo recebido para publicação em 16/10/2012

Artigo aprovado para publicação em 26/11/2012 